\section{Ks. Janusz Kręcidło MS}

Uniwersytet Kardynała Stefana Wyszyńskiego w Warszawie j.krecidlo@wp.pl

DOI: http://dx.doi.org/10.12775/BPTh.2016.034

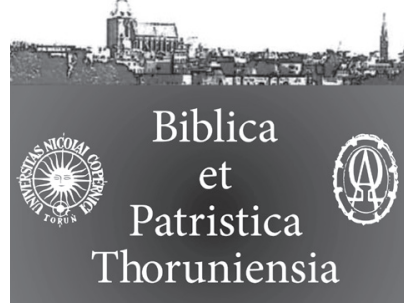

9 (2016) 4: 55-74

ISSN (print) 1689-5150

ISSN (online) 2450-7059

\title{
Modlitwa Jezusa (J 17,1-26) odczytana w perspektywie antropologii kulturowej
}

\section{The prayer of Jesus in John 17:1-26 according to social-scientific criteria}

\begin{abstract}
Streszczenie. Celem niniejszego artykułu jest lektura modlitwy Jezusa w J 17 w perspektywie kryteriów antropologicznokuturowych. Badania te poprzedzone są ukazaniem głównych kierunków interpretacyjnych tego tekstu zaproponowanych przez przedstawicieli egzegezy historyczno-krytycznej. Kolejnym krokiem jest wykazanie, że modlitwa ta wpisuje się bardzo dobrze w śródziemnomorską tradycję kulturową, w której słowa Jezusa skierowane do Ojca w J 17 interpretować można jako ostatnią wolę kogoś, kto ma niebawem umrzeć. Następnie fragment J 17,1-26 jest przeanalizowany w świetle siedmiu typów modlitwy zaproponowanych przez B.J. Malinę. Dochodzimy do wniosku, że jako całość jest to modlitwa typu heurystycznego z dominującymi elementami modlitwy prośby i modlitwy skoncentrowanej na sobie. Dalej, na podsta-

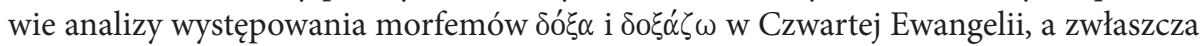
w J 17, wykazujemy, że Jezus odwołuje się w tej modlitwie do śródziemnomorskiej kategorii honoru jako podstawowej wartości człowieka. To zaś staje się przesłanką do przeanalizowania J $17 \mathrm{w}$ perspektywie relacji „patron-klient”. Wykazujemy, że Jezus przedstawia siebie w tej modlitwie jako pośrednika (brokera) pomiędzy Ojcem a uczniami. Co więcej, w obliczu powrotu do chwały nieba przekazuje On misję pośrednictwa tym, którzy uwierzą, że został posłany przez Ojca dla zbawienia świata.
\end{abstract}

Abstract. The aim of the article is to interpret the prayer of Jesus in John 17 according to social-scientific criteria. After having shown the main currents in the historical critical exegesis of the passage, the author discusses John 17 as last will of a person who is about to die. It was broadly believed in the ancient Mediterranean culture(s) that such a person is very close to God/gods and thanks to it can foresee future events. Then John 17 is analyzed in the framework of seven types of prayer proposed by B.J. Malina. The author of the article argues that John 17 as a whole is a heuristic prayer which is composed mostly of instrumental and self-focused statements. On the basis of analysis of the occurrences of the morphemes $\delta \delta^{\prime} \alpha$ and $\delta \circ \xi \alpha \zeta \omega$ in the Fourth Gospel and especially in John 17 it is stated that Jesus refers in the prayer to the Mediterranean category of 
honor as the most important human value. This prompted the author to examine John 17 in the framework of the social structure "patron-client". The author of the article argues that Jesus takes in John 17 the position of Broker - Mediator between the Father and his disciples. Moreover, in the light of his imminent return to the glory of the Father he confers the mission of being his agents (brokers) to those who have come to believe that he was the Messiah sent by the Father.

Słowa kluczowe: modlitwa Jezusa w J 17; antropologia kulturowa; doksa jako honor; patron-klient; Jezus jako Pośrednik/Broker.

Keywords: Jesus' prayer in John 17; social science; doksa as honor; patron-client; Jesus as Broker.

Ciedemnasty rozdział Ewangelii wg św. Jana jest konkluzją mów pożegnal$\checkmark$ nych Jezusa skierowanych do uczniów (rozdziały 13-17). Jest to nauczanie adresowane do grona najbliższych naśladowców w odróżnieniu do nauczania publicznego, o którym opowiadają rozdziały 1-12. Modlitwa Jezusa J 17 jest skierowana do Ojca: najpierw za siebie samego (ww. 1-5), następnie za uczniów (ww. 6-19), a na koniec za tych, którzy w Niego uwierzą dzięki świadectwu uczniów (ww. 20-26) ${ }^{1}$. W tradycji egzegetycznej przyjęło się określać ten fragment Czwartej Ewangelii modlitwą arcykapłańską Jezusa ${ }^{2}$ i uważa się go słusznie za jeden $\mathrm{z}$ teologicznie najbogatszych rozdziałów Ewangelii Jana ${ }^{3}$. Nie chcemy w niniejszym artykule dokonywać kolejnej systematyzacji teologicznych wątków tej modlitwy Jezusa. Punktem wyjścia będzie jednak pokazanie głównych propozycji egzegetów nurtu historyczno-krytycznego odnośnie do natury modlitwy Jezusa w J 17. Naszym zasadniczym celem będzie spojrzenie na J 17 z perspektywy podstawowych wartości i kryteriów świata basenu Morza Śródziemnego owego czasu.

1 Taki podział treści w J 17,1-26 wskazuje większość współczesnych komentatorów: zob. np. R.E. Brown, The Gospel according to John, vol. 2, s. 744-781; F.J. Moloney, The Gospel of John, s. 465-466. Inaczej C.S Keener, The Gospel of John. A Commentary, vol. 2, 1050-1064: 17,1-5 (wzajemna chwała Ojca i Syna), 6-24 (modlitwa za uczniów), 25-26 (konkluzja).

2 Zob. np. J. Delorme, Sacerdoce du Christ et ministère (A propos de Jean 17), s. 199-219; L. Stachowiak, Modlitwa arcykapłańska: J 17, s. 85-94; W. Thüsing, Aby wszyscy stanowili jedno (J 17). Modlitwa arcykapłańska Jezusa (J 17).

3 Zob. L. Stachowiak, Modlitwa arcykapłańska: J 17, s. 85. 


\section{Propozycje egzegetów nurtu historyczno-krytycznego odnośnie do klasyfikacji modlitwy J 17}

W tradycji egzegetycznej ukuło się określanie J 17 mianem „Modlitwa arcykapłańska”. Nomenklatura ta sięga szesnastego wieku. Po raz pierwszy tytuł ten był użyty przez luterańskiego teologa Davida Chytraeusa, po czym został powszechnie zaadoptowany w przekładach, komentarzach i dziełach egzegetycznych ${ }^{4}$. Tytuł ten każe interpretować J 17 jako modlitwę wstawienniczą. D. Chytraeus widzi w niej jednak nie modlitwę historycznego Jezusa, lecz zmartwychwstałego Pana ${ }^{5}$. S.C. Agourides zauważył zaś przejście w J 13 - 17 od dyskursu pocieszenia do modlitwy, nie definiując jednak jej typu ${ }^{6}$. B. Westcott natomiast interpretuje ten tekst jako jednocześnie modlitwę, wyznanie i objawienie ${ }^{7}$, i nadaje mu tytuł „Modlitwa konsekracyjna”. Myśl tę podejmuje w swoim komentarzu E.C. Hoskyns, wyjaśniając, że jest to konsekracja Jezusa na śmierć i zarazem przygotowanie uczniów, by mogli podjąć Jego misję ad gloriam dei ${ }^{8}$.

Próbując określić charakter owej modlitwy Jezusa, egzegeci nurtu historyczno-krytycznego wskazywali na możliwe jej starotestamentowe tło w Pwt 32, gdzie znajdujemy modlitewny hymn, dołączony do testamentu Mojżesza i pełniący funkcję rekapitulacyjną ${ }^{9}$. Z podobną rekapitulacyjną funkcją modlitw, co w J 17 mamy też do czynienia w żydowskiej literaturze apokaliptycznej i testamentowej ${ }^{10}$. Jako najbardziej reprezentatywne przykłady możemy wymienić: modlitwę wstawienniczą Mojżesza w Księdze Jubileuszów 1,19-21, modlitwę Noego przeciw demonom (tamże 10,3-6), modlitwę Abrahama o błogosławieństwo Boże dla Izaaka (tamże, 21,25), modlitwę Hioba w Testamencie Hioba (43,1-17), modlitwę Izaaka w Testamencie Izaaka 8,6-7, modlitwę Jakuba w Testamencie Jakuba 8,6-9. W utworach tych modlitwa ma wartość podsumowującą i konkludującą testament patriarchy. Taką samą funkcję rekapitulującą pełnią modlitwy zamieszczane w apokryficznych utworach apo-

4 Podaję za: G.R. Beasley-Murray, John, s. 294.

5 Aluzje do takiej modlitwy znajdujemy w jego opinii np. w 1 J 2,1; Hbr 7,25; 9,14; $\mathrm{Rz} 8,34$.

6 Zob. S.C. Agourides, The 'High-Priestly Prayer' of Jesus, s. 137-143.

7 Zob. B. Westcott, The Gospel according to St. John, s. 239.

8 Zob. E.C. Hoskyns, The Fourth Gospel, s. 494.

9 Zob. np. F. Manns, L'Évangile de Jean à la lumière du Judä̈sme, s. 394-396.

10 Zob. na ten temat: S. Mędala, Ewangelia wedtug świętego Jana (rozdziały 13-21), s. 146. 
kaliptycznych: np. 4 Księga Ezdrasza 3,1-36; 5,21-30; 12,7-9; 14,19-27; Apokalipsa Barucha (syryjska) 21,4-25; 48,1-24.

Modlitwa Jezusa w J 17 analizowana jest również w świetle dwóch traktatów z Corpus hermeticum: Poimandres i De regeneratione ${ }^{11}$. W traktacie Poimandres 1,31-32 znajdujemy modlitwę hymniczną, będącą uwielbieniem Boga i dziękczynieniem za stworzenie człowieka i objawienie się mu. Modlący się do Boga, nazywa Go Ojcem, do którego ostatecznie wstępuje, uwolniwszy się od więzów materii i śmiertelności. Bardzo podobne treści obecne są w hymnicznej modlitwie zawartej w trzynastym traktacie De regeneratione. Tutaj również autor hymnu nazywa Boga Ojcem i wysławia Go za stworzenie świata i objawiania się w nim. W modlitwie tej, podobnie jak w Czwartej Ewangelii, pojawia się także motyw Logosu, działającego wśród ludzi w imieniu Ojca. Wskazane tu podobieństwa nie dają podstaw do wyciągania wniosków odnośnie do korzystania wspólnoty Kościoła Janowego z literatury zawartej w Corpus hermeticum. W obydwu hermetycznych traktatach dialog między jednostką, a Bogiem ma charakter tajemniczy i odbywa się bez świadków. W J 17 zaś Jezus modli się do Ojca (monolog), będąc w Wieczerniku, we wspólnocie uczniów. Raczej należałoby wnioskować, że autorzy owych traktatów znali Ewangelię Jana i nią się inspirowali.

\section{Ostatnia wola kogoś, kto wkrótce umrze}

Modlitwy Jezusa w J 17 nie można interpretować w oderwaniu od kontekstu uprzedniego mów pożegnalnych rozpoczętych w 13,1. W starożytności śródziemnomorskiej owego czasu słowom wypowiadanym przez człowieka mającego niebawem umrzeć przypisywano bardzo dużą wartość. Uważano bowiem, że umierający człowiek posiada specjalną, niedostępną zwykłym śmiertelnikom, zdolność poznania i komunikowania spraw związanych z przyszłością bliskich mu osób ${ }^{12}$. Brało się to $\mathrm{z}$ przekonania, że osoba taka ma już wgląd w boskie sprawy. Platon podaje, że Sokrates przed śmiercią twierdził, że znajduje się w stanie, w którym ludzie mają szczególną zdolność przekazywania proroct $w^{13}$. U Ksenofonta czytamy natomiast, że przed śmiercią człowiek staje

11 Paralele te bada szczegółowo: C.H. Dodd, The Interpretation of the Fourth Gospel, s. $420-422$.

12 Szerzej na ten temat np. w: B.J. Malina, R.L. Rohrbaugh, Social-Science Commentary on the Gospel of John, s. 221-222.

13 Zob. Platon, Apologia, czyli Obrona Sokratesa, s. 39c: https://wolnelektury.pl/katalog/lektura/obrona-sokratesa.html (dostęp: 18.11.2016). 
się bardziej boski i dlatego jest w stanie przewidywać przyszłość ${ }^{14}$. Wirgiliusz zaś w Eneidach podaje przykład umierającego mężczyzny, który przepowiada niechybną rychłą śmierć swojego mordercy ${ }^{15}$.

Przekonanie o tym, że człowiek znajdujący się w obliczu śmierci posiada specjalny dar przewidywania i komunikowania rzeczy przyszłych widoczne jest też w tradycji biblijnej Starego Testamentu. Widać to wyraźnie na przykład w Rdz 49, gdzie patriarcha Jakub przed śmiercią udziela błogosławieństwa swoim synom, rozpoczynając mowę od słów: „Zgromadźcie się, a opowiem wam, co was czeka w czasach późniejszych" $(49,1)$. Mojżesz, po wyprowadzeniu Izraelitów z Egiptu i przeprowadziwszy ich przez pustynię, ma świadomość, że nie przejdzie Jordanu, przekazuje przywództwo Jozuemu i szeroko przepowiada przyszłość narodu w Ziemi Obiecanej (Pwt 31-34) ${ }^{16}$. Również żydowska literatura apokryficzna czasów przełomu er dostarcza licznych przykładów odzwierciedlających przekonanie o zdolności komunikowania woli Bożej odnośnie do przyszłości przez człowieka przed śmiercią. Przykładem mogą być Testament Dwunastu Patriarchów (zwłaszcza Testament Mojżesza) i Ksiega Jubileuszów (szczególnie 22,10-30) ${ }^{17}$.

Mowy pożegnalne Jezusa (J 13-16) poprzedzające jego modlitwę za uczniów w J 17 nie są czymś nieoczekiwanym i niezrozumiałym dla bezpośrednich adresatów Czwartej Ewangelii. W starożytności śródziemnomorskiej było czymś normalnym i oczekiwanym zebranie przez głowę naturalnej lub fikcyjnej (np. szkoły filozoficzne, stowarzyszenia religijne i inne) rodziny przynależących do niej ludzi, nie tylko by ich pożegnać, lecz także by wyrazić troskę i wydać ostatnie dyspozycje odnośnie do tego jak rodzina ma żyć w przyszłości. Przed śmiercią osoba taka wyrażała głębokie zatroskanie o dalszy los całej rodziny oraz każdego jej członka i przepowiadała co ważnego w ich życiu ma się wydarzyć $^{18}$. Umierająca osoba wyznaczała wtedy swojego sukcesora, mającego przewodzić rodzinie i dawała polecenia, co członkowie grupy mają czynić, by zachować jej integralność i jedność. Wszystkie słowa i gesty Jezusa w J 13-17 należy interpretować, mając świadomość tej powszechnej w kulturze śródziemnomorskiej owego czasu praktyki.

14 Zob. Ksenofont, Wychowanie Cyrusa (Cyropedia), 7.7.21.

15 Zob. Publiusz Wergiliusz Maron, Eneida, 10.729-741: http://biblioteka.kijowski.pl/ antyk\%20rzymski/publiusz\%20wergiliusz\%20maro_eneida.pdf (dostęp: 20.11.2016).

16 Inne spośród licznych przykładów tego typu świadomości w Starym Testamencie znaleźć można np. w: 1 Sm 12; 1 Krl 2,1-17; Joz 23-24; 1 Mch 2,47-70.

17 Zob. na ten temat: B.J. Malina, R.L. Rohrbaugh, Social-Science Commentary on the Gospel of John, s. 222.

18 Zob. ibidem, s. 222. 


\section{J 17 w świetle typologii modlitwy zaproponowanej przez Bruce'a J. Malinę}

B.J. Malina definiuje modlitwę jako symboliczny akt komunikacji międzyosobowej, skierowanej do kogoś, kto sprawuje kontrolę nad porządkiem istnienia ${ }^{19}$. Komunikacja taka jest nastawiona na osiągnięcie oczekiwanych rezultatów, zależnie od których możemy rozróżnić siedem typów modlitwy ${ }^{20}$. Pierwszy z tych typów to modlitwa instrumentalna (ang. instrumental), z którą mamy do czynienia, gdy indywiduum lub wspólnota modli się, prosząc o jakieś dobra, mające zaspokoić indywidualne lub wspólnotowe potrzeby. Drugi typ to modlitwa nadzorująca (ang. regulatory). Podobnie jak poprzednia jest ona również typem modlitwy prośby, z tą jednak różnicą, że proszący stawia siebie wyżej niż Boga, chcąc kontrolować Jego aktywność i decyzje, i wymóc na Nim, by zareagował zgodnie $\mathrm{z}$ wolą proszącego. Trzeci typ to modlitwa interakcyjna (ang. interactional), która ma na celu utrzymanie i pielęgnowanie dobrych międzyosobowych relacji z Bogiem. W typie tym mieszczą się takie sposoby modlitwy jak adoracja, prosta obecność przed Bogiem, codzienny rachunek sumienia w Bożej obecności itp.). Czwarty typ to modlitwa skoncentrowana na sobie (ang. self-focused). Zaliczamy tutaj np. modlitwę skruchy, uniżenia przed Bogiem, przechwalania się i wykazywania swojej wyższości wobec innych. Piąty typ to modlitwa heurystyczna (ang. heuristic), podczas której indywiduum lub wspólnota prosi Boga „powiedz mi dlaczego?”. Drogą do osiągnięcia komunikacji z Bogiem jest tu na przykład medytacja słowa Bożego albo działania Boga w życiu pojedynczego człowieka lub całej grupy. Zaliczamy tutaj wszelkiego rodzaju medytacje i modlitwy przywołujące na pomoc Ducha Świętego. Szósty typ to modlitwa wyobraźnią (ang. imaginative), podczas której modlący się próbuje/ą stworzyć środowisko modlitwy, będące przestrzenią komunikacji dostępną tylko dla niego/nich i dla Boga. Zaliczamy tu tzw. modlitwę w językach oraz modlitwy recytowane w językach nieznanych dla osób, które słuchają ich recytacji. Ostatni typ modlitwy według klasyfikacji B.J. Maliny to modlitwa informacyjna (ang. informative) polegająca na informowaniu Boga o swoich przeżyciach. Zaliczamy tu np. modlitwę wdzięczności za otrzymane łaski lub przyjęcie woli Boga.

W świetle przedstawionych powyżej kryteriów wydaje się, że modlitwa J 17 powinna być sklasyfikowana przede wszystkim jako modlitwa heurystyczna,

19 Zob. szerzej: B.J. Malina, R.L. Rohrbaugh, Social-Science Commentary on the Gospel of John, s. 246.

20 Ibidem, s. 147. 
gdyż Jezus zwracając się do Ojca przedstawia Mu Jego działanie w Nim samym oraz w uczniach. Ukazuje ona syntetycznie odniesienia interpersonalne Jezusa z Ojcem oraz z uczniami, o których autor opowiadał w trakcie całej dotychczasowej narracji Ewangelii Jana oraz wyjaśnia ich finalizację w mającej już wkrótce nadejść godzinie Jego męki, śmierci i zmartwychwstania.

Prócz tej ogólnej kategorii w J 17,1-26 wyróżnić można również elementy innych spośród siedmiu scharakteryzowanych powyżej typów modlitwy. Schematycznie ukażemy to $\mathrm{w}$ poniższej tabeli ${ }^{21}$ :

\begin{tabular}{|c|c|c|}
\hline $\mathrm{J} 17$ & Tekst & Typologia \\
\hline w. 2 & 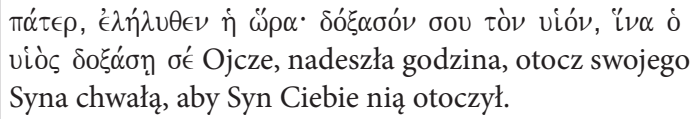 & $\begin{array}{l}\text { Instrumentalna modlitwa } \\
\text { prośby (typ 1) }\end{array}$ \\
\hline w. 3 & 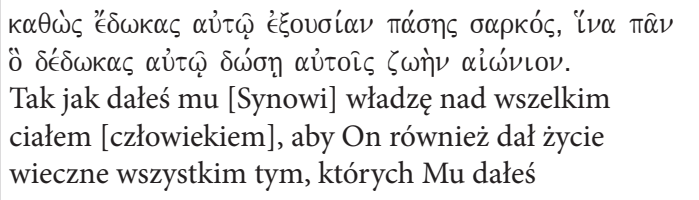 & $\begin{array}{l}\text { Instrumentalna modlitwa } \\
\text { prośby (typ 1) oraz } \\
\text { modlitwa informacyjna } \\
\text { (typ 7) }\end{array}$ \\
\hline w. 5 & 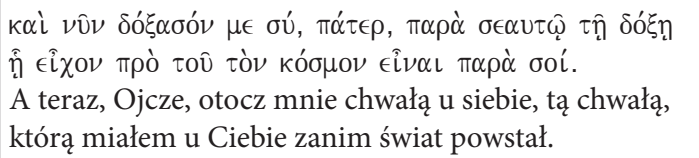 & $\begin{array}{l}\text { Instrumentalna modlitwa } \\
\text { prośby (typ 1) }\end{array}$ \\
\hline w. $6 \mathrm{a}$ & 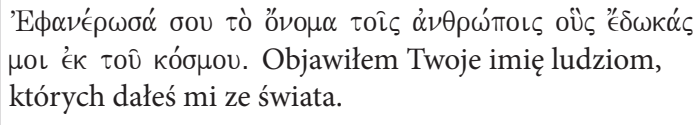 & $\begin{array}{l}\text { Modlitwa skoncentrowana } \\
\text { na sobie (typ 4) }\end{array}$ \\
\hline $\begin{array}{l}\text { ww. } \\
6 \mathrm{~b}-8\end{array}$ & 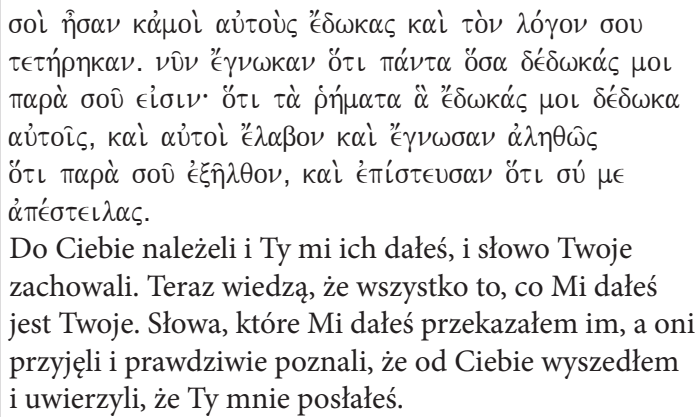 & $\begin{array}{l}\text { Modlitwa skoncentrowana } \\
\text { na sobie (typ 4) }\end{array}$ \\
\hline
\end{tabular}

21 Idziemy tutaj zasadniczo za: J.H. Neyrey, Worship in the Fourth Gospel. A Cultural Interpretation of John 14-17, s. 107-117 (artykuł dostępny także na stronie: https://www3. nd.edu/ jneyrey1/worship-John.html [8.12.2016]). 


\begin{tabular}{|c|c|c|}
\hline $\mathrm{J} 17$ & Tekst & Typologia \\
\hline w. 9 & 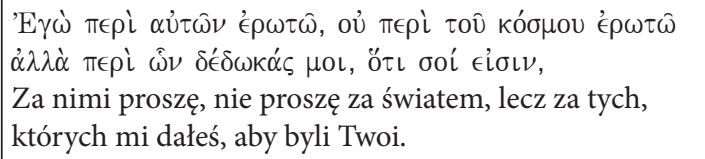 & $\begin{array}{l}\text { Instrumentalna modlitwa } \\
\text { prośby (typ 1) oraz } \\
\text { modlitwa skoncentrowana } \\
\text { na sobie (typ 4) }\end{array}$ \\
\hline w. 10 & 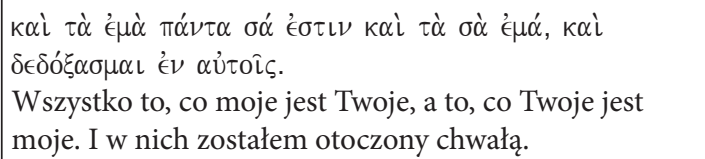 & $\begin{array}{l}\text { Modlitwa skoncentrowana } \\
\text { na sobie (typ 4) }\end{array}$ \\
\hline w. 11 & 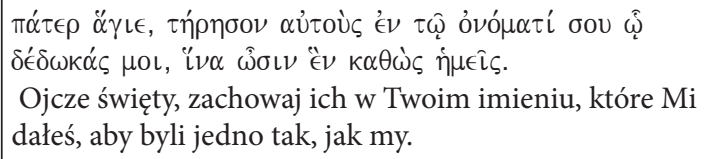 & $\begin{array}{l}\text { Instrumentalna modlitwa } \\
\text { prośby (typ 1) }\end{array}$ \\
\hline w. 12 & 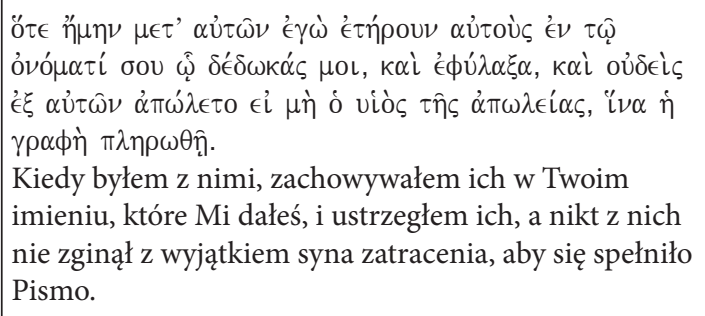 & $\begin{array}{l}\text { Modlitwa skoncentrowana } \\
\text { na sobie (typ 4) }\end{array}$ \\
\hline $\begin{array}{l}\text { ww. } \\
13-14\end{array}$ & 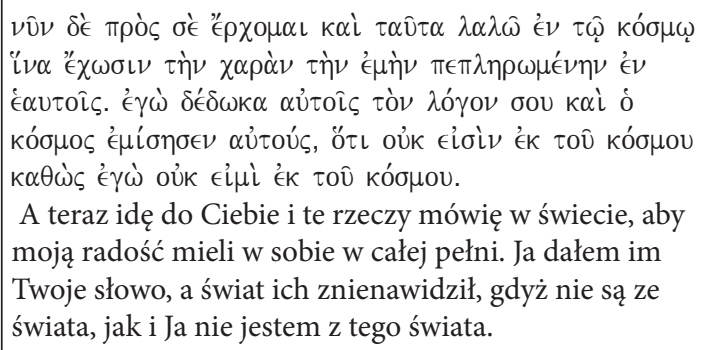 & $\begin{array}{l}\text { Modlitwa skoncentrowana } \\
\text { na sobie (typ 4) }\end{array}$ \\
\hline w. 15 & 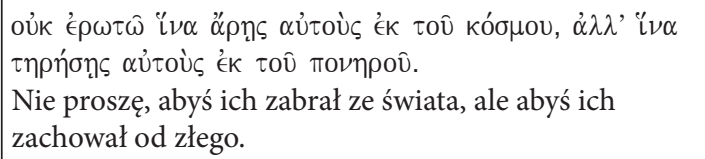 & $\begin{array}{l}\text { Instrumentalna modlitwa } \\
\text { prośby (typ 1) }\end{array}$ \\
\hline w. 16 & 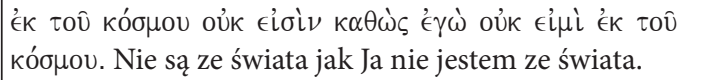 & $\begin{array}{l}\text { Modlitwa skoncentrowana } \\
\text { na sobie (typ 4) }\end{array}$ \\
\hline w. 17 & 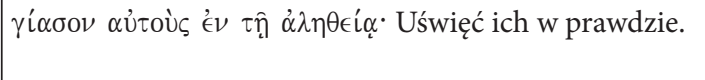 & $\begin{array}{l}\text { Instrumentalna modlitwa } \\
\text { prośby (typ 1) }\end{array}$ \\
\hline
\end{tabular}




\begin{tabular}{|c|c|c|}
\hline $\mathrm{J} 17$ & Tekst & Typologia \\
\hline $\begin{array}{l}\text { ww. } \\
18-19\end{array}$ & 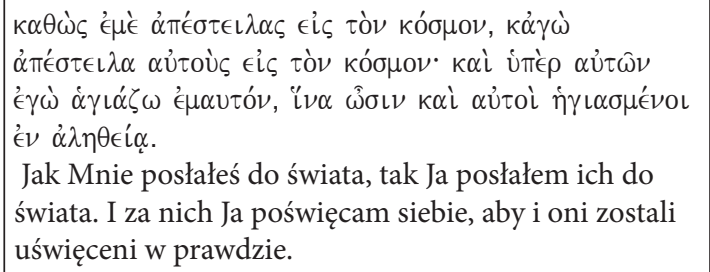 & $\begin{array}{l}\text { Modlitwa skoncentrowana } \\
\text { na sobie (typ 4) }\end{array}$ \\
\hline $\begin{array}{l}\text { ww. } \\
20- \\
22 \mathrm{a}\end{array}$ & 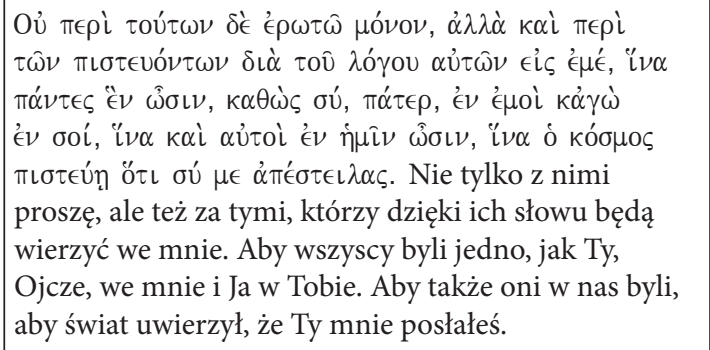 & $\begin{array}{l}\text { Modlitwa skoncentrowana } \\
\text { na sobie (typ 4) oraz } \\
\text { instrumentalna modlitwa } \\
\text { prośby (typ 1) }\end{array}$ \\
\hline $\begin{array}{l}\text { ww. } \\
22 \mathrm{~b}- \\
23\end{array}$ & 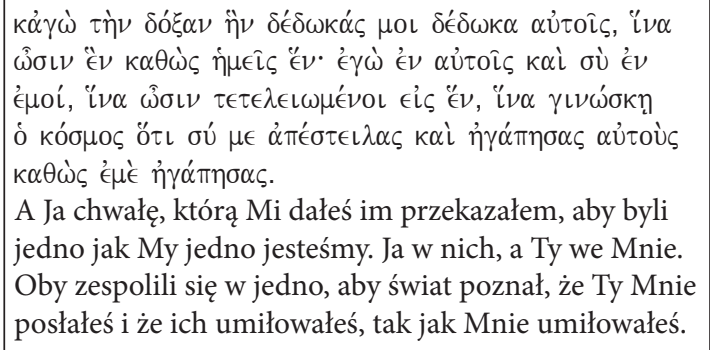 & $\begin{array}{l}\text { Modlitwa skoncentrowana } \\
\text { na sobie (typ 4) }\end{array}$ \\
\hline w. 24 & 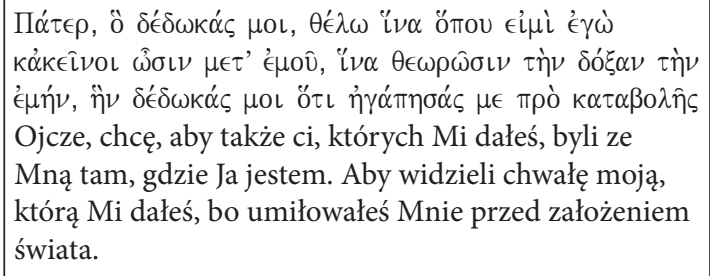 & $\begin{array}{l}\text { Instrumentalna modlitwa } \\
\text { prośby (typ 1) }\end{array}$ \\
\hline $\begin{array}{l}\text { ww. } \\
25-26\end{array}$ & 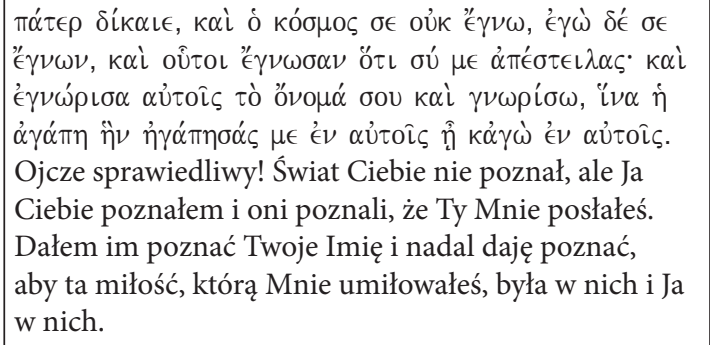 & $\begin{array}{l}\text { Modlitwa skoncentrowana } \\
\text { na sobie (typ 4) }\end{array}$ \\
\hline
\end{tabular}


W modlitwę typu heurystycznego J 17,1-26 wpisują się także bardzo obficie i wyraźnie elementy instrumentalnej modlitwy prośby (typ 1): wersety 2, 5, 11, $15-16,17,21-22,24$ oraz modlitwy skoncentrowanej na sobie (typ 2): wersety $6-8,9,10,12,13-14,16,18-19,20,23-24,25-26$. Sporadycznie także pojawia się typ modlitwy informacyjnej $(17,3)$. Wezwania modlitwy instrumentalnej (typ pierwszy) rozpoczyna Jezus zazwyczaj od czasownika „prosić” wyrażonego w imperatywie aorystu. Treścią owych próśb są konkretne potrzeby wspólnoty, które Ojciec ma zabezpieczyć. Są to potrzeby duchowe: zwłaszcza chwała Boża, jedność - rozumiana jako pogłębiona relacja z Bogiem i wewnątrz wspólnoty. Natomiast wezwania modlitwy skoncentrowanej na sobie kieruje Jezus do Ojca w pierwszej osobie liczby pojedynczej, przypominając swoją troskę o uczniów w dotychczasowej działalności wśród nich w Jego imieniu: np. „objawiłem Twoje imię ludziom” (17,6a), „słowo, które mi dałeś przekazałem im” (17,8), „kiedy byłem z nimi, zachowywałem ich w Twoim imieniu” $(17,12)$, “dałem im Twoje słowo" $(17,14)$, „dałem im poznać Twoje Imię" $(17,26)$. Jezus zatem wypowiada do Ojca wobec uczniów swoje przekonanie o wypełnieniu misji, którą Mu powierzył w świecie i wyraża gotowość kontynuowania tego dzieła, mającego się sfinalizować w Jego "godzinie”.

Dokonane tu zestawienia ukazują Jezusa jako pośrednika zbawienia i reprezentanta uczniów wobec Ojca. Jest to wyraźne nawiązanie do śródziemnomorskiej kultury honoru i wstydu/hańby, zwłaszcza do struktury relacji społecznych opartych na mechanizmie „patron - klient”. W dalszej części artykułu najpierw krótko wskażemy elementy kultury honoru w J 17, a następnie zajmiemy się analizą tej perykopy, ukazując modlitwę Jezusa jako posłanego przez Ojca Pośrednika wstawiającego się za uczniów.

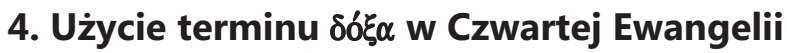 jako przesłanka odwoływania się do honoru w J 17}

Liczne wystąpienia rzeczownika $\delta o ́ \xi \alpha$ oraz czasownika $\delta o \xi \alpha ́ \zeta \omega$ w Ewangelii wg św. Jana są najczęściej interpretowane w znaczeniu „chwała”, „oddawać chwałę". Już Ernst Käsemann rozwija tezę, że wcielenie Jezusa jest rozumiane w Czwartej Ewangelii jako projekcja chwały preegzystującego Logosu, a Jego męka i śmierć to droga powrotu to tej chwały ${ }^{22}$. Autorzy generalnie podzielają opinię amerykańskiego biblisty Raymunda E. Browna, który w swoim komentarzu do Ewangelii Jana stwierdził, że idea chwały w tym utworze odzwiercie-

22 Zob. E. Käsemann, Testament of Jesus: Study of the Gospel of John in the Light of Chapter 17, s. 18-20. 
dla koncepcję chwały Bożej w Starym Testamencie rozumianej jako widzialna manifestacja Jego obecności w „aktach mocy”23. Po tej linii interpretacji idą również inni współcześni egzegeci ${ }^{24}$.

Daje się jednak odnotować w Czwartej Ewangelii liczne użycia morfemów $\delta o ́ \xi \alpha$ i $\delta o \xi \alpha ́ \zeta \omega$, których kontekst wyraźnie wskazuje, że nie desygnują manifestacji chwały Bożej. Co więcej w niektórych wystąpieniach morfemy te pozbawבוד wione są teologicznych konotacji związanych z hebrajskim rzeczownikiem przekładanym w Septuagincie jako $\delta o ́ \xi \alpha$. W tych przypadkach należy analizować wystąpienia $\delta o ́ \xi \alpha$ i $\delta o \xi \alpha ́ \zeta \omega$ w Ewangelii Jana na tle ich semantyki w grece klasycznej i hellenistycznej, gdzie oznaczają one „opinię” na jakiś temat albo „dobrą reputację" czyli „honor” 25 .

Intuicje te znajdują potwierdzenie w badaniach słownictwa nowotestamentowego prowadzonych przez J.P. Louwa i E.A. Nindę i opublikowanych w słowniku, którego budowa oparta jest na domenach semantycznych. Okazuje się, że morfemy $\delta o ́ \xi \alpha$ i $\delta o \xi \alpha ́ \zeta \omega$ mają w Nowym Testamencie dosyć szerokie spektrum znaczeniowe, gdyż oznaczają takie rzeczywistości jak splendor, jasność, moc, a także honor, uznanie, respekt jako cechy społecznego statusu człowieka ${ }^{26}$.

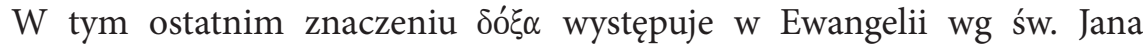
np. w 5,41-44; 7,18;12,43. W pierwszym z tych wystąpień mamy do czynienia z apologią Jezusa wobec establishmentu żydowskiego chcącego wydać Go na śmierć po uzdrowieniu kalekiego człowieka w szabat przy sadzawce Owczej. Jezus stwierdza wówczas: „Nie odbieram chały [w znaczeniu „honoru; $\delta$ ó $\xi \alpha$ ] od ludzi [...]. Jak możecie uwierzyć, skoro od siebie nawzajem odbieracie chwałę/

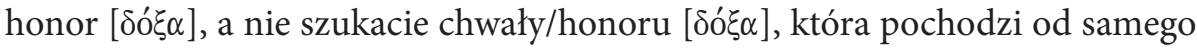
Boga” (5,41-44). W 7,18 Jezus zaś stwierdza: „Kto mówi we własnym imieniu, ten szuka własnej chwały/honoru ( $\left.\delta \delta^{\prime} \alpha\right)$. Kto zaś szuka chwały/honoru ( $\left.\delta \xi_{\xi} \alpha\right)$ Tego, który go posłał, ten godzien jest wiary i nie ma w nim nieprawości”. Końcowa wypowiedź komentatora, oceniającego powody częściowej porażki publicznego nauczania Jezusa brzmi następująco: „Niemniej jednak i spośród przywódców wielu w Niego uwierzyło, ale z obawy przed faryzeuszami nie przyznawali się, aby ich nie wyłączono z synagogi. Bardziej bowiem umiłowa-

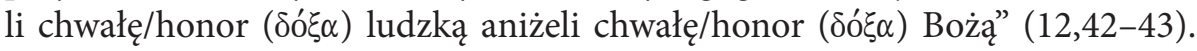
$\mathrm{W}$ oparciu o trzy przytoczone tu fragmenty z Ewangelii Jana można wyciągnąć wniosek, że termin $\delta o ́ \xi \alpha$ stosowany jest przez autora również w znaczeniu ho-

23 Zob. R.E. Brown, The Gospel according to John, vol. 2, s. 503.

24 Dyskusję przedstawia np. R.A. Piper, Glory, Honor and Patronage in the Fourth Gospel: Understanding the Doxa Given to Disciples in John 17, s. 283-285.

25 Zob. C.H. Dodd, The Interpretation of the Fourth Gospel, s. 206.

26 Zob. J.P. Louw, E.A. Nida, Greek-English Lexicon of the New Testament, s. 734-736. 
nor, a zatem morfem ten odnosi się do najbardziej cenionej wartości człowieka $\mathrm{w}$ aspekcie indywidualnym i kolektywistycznym.

Na podstawie tych przesłanek z kontekstu uprzedniego J 17 należy spojrzeć pokrótce na zakres semantyczny morfemów $\delta o ́ \xi \alpha$ i $\delta o \xi \alpha ́ \zeta \omega$ tej perykopie. Cza-

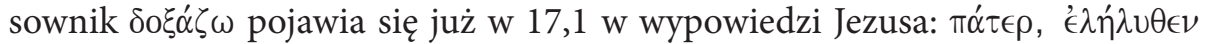

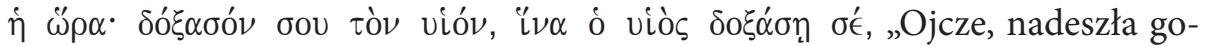
dzina. Otocz chwałą Twojego Syna, aby Syn Ciebie otoczył chwałą”. Niewątpliwie mamy tu do czynienia z nacechowaniem teologicznym morfemu $\delta \circ \xi \alpha \zeta \zeta$, implikującym manifestację Bożego majestatu w "godzinie” Jezusowej męki, śmierci i zmartwychwstania ${ }^{27}$. Dla ludzi wyrosłych w cywilizacji śródziemnomorskiej owego czasu, zwłaszcza nie-Żydów, takie wezwanie Jezusa skierowane do Ojca mogło mieć jednak również odcień przezwyciężenia skandalu krzyżowej śmierci, poprzez odwołanie się do najwyższego honorowego statusu tożsamości Jezusa i Jego misji.

Tego typu wniosek nasuwa się także przy analizie kolejnego wystąpienia

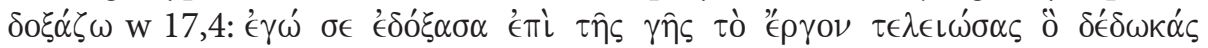

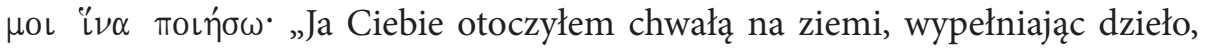
które mi dałeś do wykonania”. Mamy tutaj do czynienia z klasycznym rozumieniem morfemu $\delta$ $\xi \alpha ́ \zeta \omega$ jako przydania splendoru majestatowi Ojca poprzez wypełnienie przez Jezusa powierzonego Mu dzieła zbawienia. Na poziomie egzystencjalnym zaś ów teologiczny koncept można interpretować jako powiększenie honoru Ojca, uzmysłowienie adresatom Jego wielkości i wyjątkowości. $\mathrm{Z}$ wyraźnie teologicznym znaczeniem tego morfemu w sensie chwały mamy do

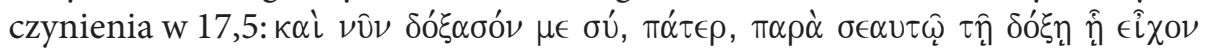

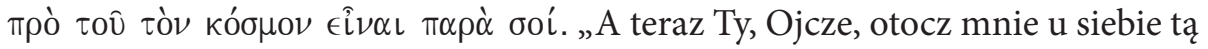
chwałą, którą miałem u Ciebie przed [powstaniem/stworzeniem] świata”. Jest to niewątpliwie nawiązanie do teologicznego znaczenia tego morfemu wprowadzonego już w prologu w 1,14: „A słowo stało się ciałem i zamieszkało wśród nas. I oglądaliśmy Jego chwałę ( $\delta o ́ \xi \alpha)$, chwałę ( $\delta o ́ \xi \alpha)$, jaką Jednorodzony otrzymuje od Ojca, pełen łaski i prawdy".

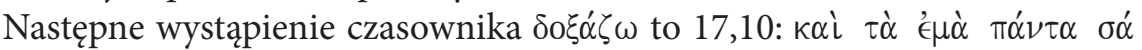

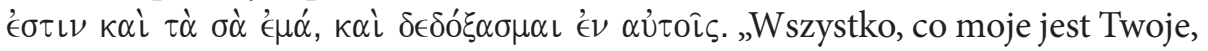
a Twoje jest moje, i doznałem chwały/honoru w nich". W tej wypowiedzi Jezusa akcent jest położony raczej nie na aspekcie teologicznym, lecz na honorze Jezusa, który powiększył się i trwa (forma perfectum: $\delta \epsilon \delta o ́ \xi \alpha \sigma \mu \alpha \iota)$ dzięki Jego nauczaniu i dziełom mocy Bożej. Z ambiwalentnym znaczeniem $\delta o ́ \xi \alpha$ mamy do

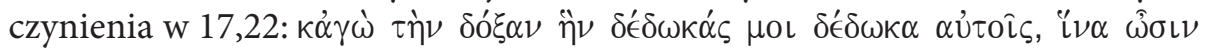

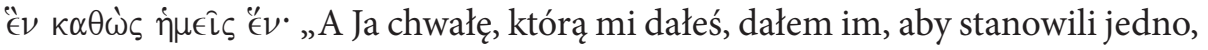

27 Szerzej zob. C.S. Keener, The Gospel of John. A Commentary, s. 1052-1055. 
jak my jesteśmy jedno". Chodzi tutaj o Bożą chwałę, która została objawiona ludziom w słowach i czynach Jezusa, które pozwoliły im dostrzec Jego pochodzenie od Ojca oraz jedność osób Boskich, która ma być wzorem i źródłem jedności uczniów ${ }^{28}$. Z przynależności do relacji Ojca z Synem ma wynikać dla uczniów uczestnictwo w ich szczególnej chwale oraz ich wyjątkowy honorowy status. W ostatnim wystąpieniu morfemu $\delta o ́ \xi \alpha ~ w$ analizowanej modlitwie Jezusa w J 17 jest on użyty w sensie czysto teologicznych, w znaczeniu oglą-

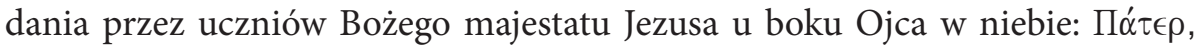

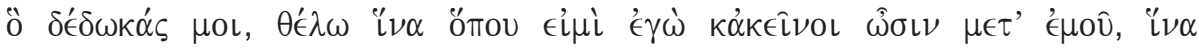

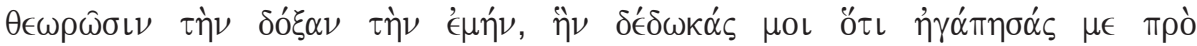

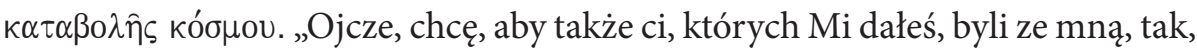
gdzie Ja jestem, aby widzieli chwałę moją, którą mi dałeś, bo umiłowałeś mnie od założenia świata" $(17,24)$.

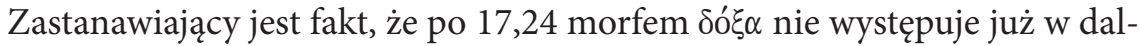
szej narracji Czwartej Ewangelii (natomiast czasownik $\delta$ o $\xi \alpha \zeta \omega$ tylko jeden raz w 21,19) ${ }^{29}$. Można stąd wyciągnąć wniosek, że J 17 stanowi tematyczny klimaks, gdy idzie o objawienie chwały i honoru Jezusa. Dalsze rozdziały Ewangelii Jana ukazywać będą, w jaki sposób wyjątkowy honor Jezusa potwierdza się w dziele Jego męki, krzyżowej śmierci, powstania z martwych i ukazywania się uczniom. Obserwacja ta pozwala nam lepiej dostrzec konkludującą wartość modlitwy Jezusa nie tylko w perspektywie mów pożegnalnych J 13-16, lecz także całej dotychczasowej narracji Ewangelii Jana ${ }^{30}$.

Na podstawie przedstawionego tu skrótowo zestawienia użycia morfemów $\delta o ́ \xi \alpha$ i $\delta o \xi \alpha ́ \zeta \omega$ w J 17 należy wyciągnąć wniosek, że Jezus w swojej modlitwie operuje nimi na dwóch poziomach znaczeniowych. Z jednej strony wpisuje się $\mathrm{w}$ tradycję biblijną, według której desygnują one widzialną manifestację Bożej chwały, którą posiada On w sobie samych jak i Bożą chwałę, która objawia się ludziom w posłannictwie Jezusa. Z drugiej zaś strony niektóre z wystąpień tych morfemów w J 17 kładą większy nacisk na honor jako wyznacznik wartości oraz statusu społecznego. Wystąpienia te uprawniają nas do analizy J 17 w perspektywie relacji „patron-klient”, do której Jezus się tu w naszej opinii odwołuje.

28 Inaczej wystąpienie to interpretuje R.A. Piper, Glory, Honor and Patronage in the Fourth Gospel, s. 285-288, który widzi tu jedynie wyjątkowy honorowy status uczniów otrzymany od Boga.

29 Zob. R.A. Piper, Glory, Honor and Patronage in the Fourth Gospel, s. 295.

30 Por. ibidem. 


\section{J 17 w perspektywie „patron-klient" - Jezus jako Pośrednik (Broker)}

Patronat jest definiowany w metodologii social-science jako dobrowolna relacja między osobami o nierównym statusie społecznym ${ }^{31}$. Nie jest to relacja prawnie usankcjonowana ${ }^{32}$. Osoby, które ją zawiązują, wchodzą w związek zależności pociągający za sobą prawa i obowiązki. Zależność „patron-klient” obejmuje całe spektrum relacji społecznych takich jak: ojciec/syn, pan/klient (wasal), właściciel/dzierżawca, polityk/jego stronnik, nauczyciel/uczeńn ${ }^{33}$. Według tej wzorcowej relacji opisywano też relację między Bogiem, a człowiekiem. Zależność „patron-klient” była ważnym czynnikiem spajającym relacje społeczne w kulturze śródziemnomorskiej czasów Nowego Testamentu. Miała ona konsekwencje w postaci możliwości pozyskania większego statusu społecznego zarówno przez patrona jak i wasala, a dla tego ostatniego skutkowała także korzyściami ekonomicznymi. Wejście w relację „patron-klient” pociągało za sobą konkretne obustronne zobowiązania. Im więcej klientów patron posiadał, tym cieszył się w społeczeństwie większym prestiżem. Miał w zamian dbać o odpowiednio wysoki status materialny swoich wasali, zobowiązany był stawać w ich obronie, gdy groziło im niebezpieczeństwo, starał się pomagać im w rozwoju kariery zawodowej itp. Klient zaś stawał się członkiem rodziny patrona, był pod jego władzą i powinien być do jego dyspozycji w różnych życiowych sprawach. Jego nadrzędnym zadaniem była dbałość o utrzymanie i pomnażanie honoru swojego pana.

Formą relacji „patron-klient” było pośrednictwo (ang. brokerage) ${ }^{34}$. Funkcją pośrednika (ang. broker) było pełnienie roli mediatora pomiędzy patronem a wasalem. Potrzeba taka rodziła się wówczas, gdy osoby, pragnące wejść w relację "patron-klient” pochodziły z odległych warstw społecznych. Niepisane zasady wchodzenia $\mathrm{w}$ relację "patron-klient” kazały w takich przypadkach zwrócić się osobom z niskiej warstwy społecznej do mediatora pochodzącego z odpowiednio wysokiej klasy społecznej, umożliwiającej mu w ich imie-

31 Szerokie omówienie tych spraw znaleźć można np. w: J.H. Elliott, Patronage and Clientage, s. 144-158; E.C. Stewart, Social Stratification and Patronage in Ancient Mediterranean Societies, s.156-166; J. Kręcidło, Honor $i$ wstyd w interpretacji Ewangelii, s. 40-43.

32 Model „patron-klient” omawiają gruntownie np. S.N. Eisenstadt, L. Roniger, $\mathrm{Pa}$ tron-Client Relations as a Model of Structuring Social Exchange, s. 42-77.

33 Zagadnienia te kompetentnie omawia np. H. Moxnes, Patron-Client Relationship and the New Community in Luke-Acts, s. 241-268.

34 Zob. R.A. Piper, Glory, Honor and Patronage in the Fourth Gospel, s. 295-298. 
niu nawiązanie kontakt z osobą, którą chcieli prosić o patronat. Brokerami jak i wasalami mogli być zarówno pojedynczy ludzie, jak i całe grupy społeczne o charakterze etnicznym, zawodowym, religijnym itp. Jak to wykazaliśmy gdzie indziej, w mowach pożegnalnych J 13-17 Jezus jest ukazywany przez autora właśnie jako pośrednik/broker w relacji uczniów z Ojcem w niebie ${ }^{35}$.

Naszym zadaniem w dalszej części artykułu będzie aplikacja modelu „patron-klient" $\mathrm{z}$ wyeksponowaniem roli Jezusa jako pośrednika (brokera) pomiędzy Ojcem a uczniami do analizy modlitwy J 17. Należy tu nadmienić, że pośrednicząca rola Jezusa $\mathrm{w}$ relacji Ojca $\mathrm{z}$ uczniami nie jest strukturą, która pojawia się dopiero w rozdziałach 13-16 Ewangelii Jana i znajduje kulminację w J 17. Powoływanie się Jezusa na wyjątkową relację z Ojcem, który posłał Go na świat jest bowiem jednym z głównych argumentów uzasadniających Jego zbawczą misję w świecie ${ }^{36}$. Jezus wielokrotnie mówi o tym zarówno uczniom, którzy w Niego uwierzyli, jak i oponentom. Przytoczmy tu dla ilustracji kilka Jego wypowiedzi: „Nie znaczy to, aby ktokolwiek widział Ojca, jedynie Ten, który jest od Boga, widział Ojca” (6,46); „Ja i Ojciec jedno jesteśmy” (10,30); „Kto mnie zobaczył, zobaczył także i Ojca. Dlaczego więc mówisz: «Pokaż nam Ojca?», Czy nie wierzysz, że Ja jestem w Ojcu, a Ojciec we mnie? Słów tych, które wam mówię, nie wypowiadam od siebie. Ojciec, który trwa we mnie, On sam dokonuje tych dzieł. Wierzcie mi, że ja jestem w Ojcu, a Ojciec we mnie" (14,9b-11a). Strategia ta bardzo mocno wybrzmiewa już w prologu (1,1-18) Ewangelii Jana, stanowiącym rodzaj paratekstu do lektury całego dzieła. Jezus jest tu ukazany jako Słowo, które było u Boga i było Bogiem $(1,1)$, następnie zostało wcielone i zamieszkało wśród ludzi, którzy oglądali Jego chwałę $(\delta o ́ \xi \alpha)(1,14)$. W zakończeniu prologu zaś pośrednicząca funkcja Jezusa w relacji Ojca z ludźmi jest wyrażona explicite: „Boga nikt nigdy nie widział, Ten

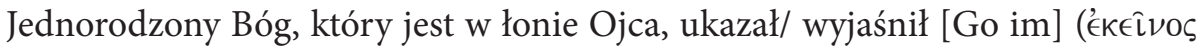

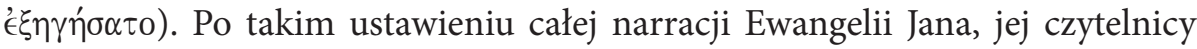
poznają kolejne epizody z przeświadczeniem o pośredniczącej funkcji Jezusa. Wszystko, co Jezus mówi i czyni, jest jednocześnie słowem i czynem Ojca, który Go posłał. Jezus jest zatem ukazany w Czwartej Ewangelii jako doskonały Pośrednik pomiędzy Ojcem, a uczniami.

35 Zob. publikację: J. Kręcidło, The Spirit Paraclete and Jesus in the Gospel of John, s. 91-108. W J 13-17 również Duch Paraklet pełni funkcję pośrednika pomiędzy Jezusem i Ojcem a uczniami. Zob. na ten temat monografię (praca doktorska): T. Gates Brown, Spirit in the Writings of John. Johannine Pneumatology in Social-Scientific Perspective.

36 Szeroko sprawę relacji Jezusa z Ojcem w Ewangelii wg św. Jana omawia: M.S. Wróbel, Obraz Boga Ojca, s. 11-38. Zob. też: J. Kręcidło, Świadectwo Boga Ojca o Jezusie w Ewangelii wg św. Jana, s. 147-167. 
J 17 to finalizacja mów pożegnalnych Jezusa do uczniów, będąca modlitwą, w której powierza ich dalszy los Ojcu, wobec zbliżającej się Jego śmierci. Jezus przyjmuje w tej modlitwie funkcję pośrednika (brokera), wstawiającego się za wszystkich tych, którzy poprzez wiarę przyjęli Jego pośrednictwo wobec Ojca ${ }^{37}$. Intencję tę Jezus wypowiada już w pierwszych słowach swojej modlitwy: „Ojcze, nadeszła godzina. Otocz swego Syna chwałą (czasownik

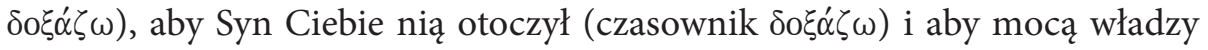
udzielonej $\mathrm{Mu}$ przez Ciebie nad każdym człowiekiem dał życie wieczne wszystkim tym, których Mu dałeś” (17,1b-2). Występujący dwukrotnie w tej wprowadzającej wypowiedzi Jezusa czasownik $\delta \xi_{\alpha} \alpha \omega$ naprowadza czytelnika na myślenie w kategoriach przymnożenia chwały rozumianej teologicznie jako majestat, a egzystencjalnie jako splendor, honor (zob. powyżej) ${ }^{38}$. Majestat i honor Ojca i Jezusa są tu ukazane jako wartości relacyjne uzależnione od kondycji uczniów Jezusa. Honor Ojca i Jezusa zostanie pomnożony przez to, że ci, których $\mathrm{Mu}$ powierzył w opiekę osiągną życie wieczne, rozumiane tutaj jako poznanie Ojca będącego Jedynym prawdziwym Bogiem oraz poznanie tożsamości Jezusa jako jedynego Pośrednika: „A to jest życie wieczne: aby poznali Ciebie, jedynego prawdziwego Boga oraz Tego, którego posłałeś, Jezusa Chrystusa" $(17,3)$. Jezus zatem doskonale wypełnia powierzone mu przez Ojca i przyjęte przez uczniów przez wiarę w Niego zadanie pośrednika. Rezultatem tego pośrednictwa jest wzrost chwały/honoru Ojca (i Jego samego), z którym jest jedno $(10,30)$ oraz posiadanie życia wiecznego, będącego udziałem w chwale/honorze Ojca i Syna.

Funkcja Jezusa jako pośrednika w relacji ludzi z Ojcem wpisuje się doskonale w podstawową strukturę tej modlitwy. W pierwszej jej części $(17,1-$ -5), jak to pokazaliśmy powyżej, Jezusa koncentruje się na uświadomieniu uczniom - modlitwa jest skierowana do Ojca, ale z pewnością jest wypowiadana na głos - że uczestniczą w chwale/honorze współdzielonym przez Niego i Ojca i że dzięki temu posiadają już życie wieczne ${ }^{39}$. W drugiej części $(17,6-19)$ mówi do Ojca w obecności uczniów o tym w jaki sposób realizuje swoją funkcję pośrednika. W trzeciej zaś części (17,20-26) mówi o swoim pośrednictwie pomiędzy Ojcem a tymi, którzy w przyszłości w Niego uwierzą, czyli o potencjalnych uczniach, do których dotrą słowa świadectwa Ewange-

37 Por. B.J. Malina, R.L. Rohrbaugh, Social-Science Commentary on the Gospel of John, s. 244.

38 Por. F.J. Moloney, The Gospel of John, s. 460-461.

39 Zob. też: B.J. Malina, R.L. Rohrbaugh, Social-Science Commentary on the Gospel of John, s. 244. 
lii. Spójrzmy pokrótce w jaki sposób Jezus realizuje swoje pośrednictwo na dwóch ostatnich etapach.

Nadrzędnym celem Jego działań wobec ludzi w świecie, wyrażanych w postaci słów i czynów, było objawienie im Ojca: „Objawiłem imię Twoje

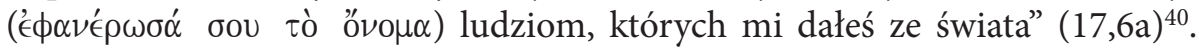
Ludzie ci nie byli obcy Ojcu, gdyż należeli już uprzednio do Niego i zostali przekazani Jezusowi $(17,6 \mathrm{~b})$. Nie byli jednak tego świadomi i dopiero dzięki uznaniu pośrednictwa Jezusa poznali, że wszystko pochodzi od Ojca $(17,7)$. Pośrednictwo to realizowało się przede wszystkim poprzez głoszenie słów, które Ojciec polecił Mu im przekazać. Ci zaś, którzy przyjęci te słowa, uwierzyli w pośrednictwo Jezusa $(17,8)$.

Po przedstawieniu Ojcu dotychczasowych dokonań wobec uczniów, Jezus pośredniczy w wypraszaniu dla nich opieki Ojca wtedy, gdy On od nich odejdzie. Zanim jednak Jezus wypowie te prośby, odwołuje się w modlitwie do Ojca do wyjątkowości ich relacji: „Wszystko bowiem moje jest Twoje, a Twoje jest moje, i w nich zostałem otoczony chwałą" $(17,10)$. Skuteczność pośredniczącej misji historycznego Jezusa wobec uczniów przyczyniła się do wzrostu Jego chwały/honoru w ich ocenie. Jest to jednocześnie gwarantem tego, że jeżeli Ojciec nadal zechce być ich „Patronem”, to również w przyszłości dochowają wierności zobowiązaniom wasala. W momencie powrotu Jezusa do Ojca, wypełnia się powierzona Mu wobec uczniów misja i przestaje pełnić wobec nich funkcję pośrednika w takim zakresie, w jakim czynił to do tej pory.

Istotną treścią modlitwy Jezusa odnośnie do przyszłości uczniów jest prośba o zachowanie ich w jedności wzorowanej na jedności Ojca i Syna: „Ojcze Święty, zachowaj ich w Twoim imieniu, które Mi dałeś, aby tak jak my stanowili jedno" $(17,11)$. Zachowanie jedności wewnątrz wspólnoty uczniów jest gwarantem tego, że nikt $\mathrm{z}$ nich się nie zatraci $(17,12)$. Jedność $\mathrm{w}$ Chrystusie ma być dla nich źródłem pełnej radości, pomimo nienawiści ze strony świata $(17,13-$ -14). Przeżywanie życia w Jezusie wyłącza ich ze świata, w którym mają żyć ze świadomością, że do niego nie należą. Żyjąc w świecie uczniowie są narażeni na ataki zła, dlatego też Jezus prosi Ojca, by zachował ich od złego $(17,15)$. Kolej-

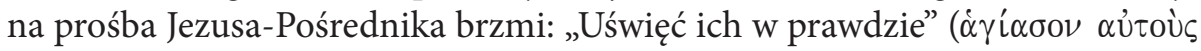

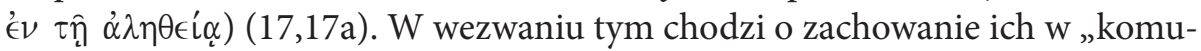
nii z Synem i Ojcem"41, w której uczniowie mogą trwać poprzez posłuszeństwo słowu Ojca, będącego prawdą (17,17b). Na koniec modlitwy za uczniów Jezus

40 Szersze wyjaśnienie tego fragmentu: R.E. Brown, The Gospel according to John, vol. 2, s. 754-756.

41 Zob. S. Mędala, Ewangelia według świętego Jana (rozdziały 13-21), s. 160. 
podkreśla, że przekazał im misję pośrednika ${ }^{42}$ : „Jak Ty mnie posłałeś na świat, tak i Ja ich na świat posłałem" $(17,17)$. Gwarantem skuteczności ich pośrednictwa pomiędzy Ojcem, a tymi, którym będą świadczyć o Jezusie jest złożenie przez Niego samego siebie w ofierze krzyżowej.

Ostatnią część modlitwy do Ojca otwiera Jezus słowami: „Nie tylko za nimi proszę, ale i za tymi, którzy dzięki ich słowu będą wierzyć we Mnie” $(17,20)$. Jest to zatem modlitwa za wszystkich, do których dotrą słowa Dobrej Nowiny o Jezusie i którzy przyjmą je $\mathrm{z}$ wiarą. Podstawową prośbą $\mathrm{w}$ ich intencji jest, podobnie jak w przypadku uczniów, zachowanie jedności zakorzenionej w jedności Ojca i Syna $(17,21 a)^{43}$. Zjednoczenie z Ojcem i Synem tych, którzy uwierzą będzie dla świata znakiem, który pozwoli mu uwierzyć, że Ojciec posłał Jezusa dla zbawienia świata $(17,21 b)$. Źródłem jedności uczniów ma być także udział w chwale Jezusa, którą należy tu interpretować jako partycypację w Jego niezwykłym Boskim honorze ${ }^{44}$. Trwanie w jedności tych, którzy przejmą przekazaną im przez Jezusa misję pośredników będzie dla świata znakiem tego, że Ojciec posłał Jezusa dla zbawienia świata oraz znakiem miłości Ojca do Jezusa i do nich $(17,23)$.

Ostatnią prośbą Jezusa jest to, by Ojciec pozwolił uczestniczyć w chwale nieba tym, których Mu dał i którzy w Niego uwierzyli $(17,24 a)^{45}$. Jezus jest przekonany o spełnieniu tej prośby przez Ojca, gdyż jest pewien miłości Ojca do siebie $(17,24 b)^{46}$. Dzięki Jego pośrednictwu wzajemna miłość Ojca i Syna staje się udziałem tych, którzy wierzą w Jego posłannictwo $(17,26)$.

\section{Bibliografia}

Agourides S.C., The 'High-Priestly Prayer' of Jesus, Studia Evangelica 4 (1968), s. 137-143 .

Beasley-Murray G.R., John, Word Biblical Commentary 36, Waco 1987.

Brown R.E., The Gospel according to John, vol. 1-2, The Anchor Bible 29A, New York 1966-1970.

Delorme J., Sacerdoce du Christ et ministère (A propos de Jean 17). Sémantique et théologie biblique, Recherches de science religieuse 62 (1974), s. 199-219.

42 Zob. F.J. Moloney, The Gospel of John, s. 466-467.

43 Por. B.J. Malina, R.L. Rohrbaugh, Social-Science Commentary on the Gospel of John, s. 245 .

44 Szerszą argumentację podaje: R.A. Piper, Glory, Honor and Patronage in the Fourth Gospel: Understanding the Doxa Given to Disciples in John 17, s. 295-309.

45 Zob. C.S. Keener, The Gospel of John. A Commentary, s. 1061-1064.

46 Por. R.E. Brown, The Gospel according to John, vol. 2, s. 772. 
Dodd C.H., The Interpretation of the Fourth Gospel, Cambridge 1978.

Eisenstadt S.N., Roniger L., Patron-Client Relations as a Model of Structuring Social Exchange, Comparative Studies in Society and History 22 (1980), s. 42-77.

Elliott J.H., Patronage and Clientage, w: R.L. Rohrbaugh (red.), The Social Sciences and the New Testament Interpretation, Peabody 2003, s. 144-158.

Gates Brown T., Spirit in the Writings of John. Johannine Pneumatology in Social-Scientific Perspective, London 2004.

Hoskyns E.C., The Fourth Gospel, red. F.N. Davey, London 1947.

Keener C.S., The Gospel of John. A Commentary, vol. 2, Peabody 2003.

Käsemann E., Testament of Jesus: Study of the Gospel of John in the Light of Chapter 17, Canterbury 1968.

Kręcidło J., Honor $i$ wstyd $w$ interpretacji Ewangelii. Szkice z egzegezy antropologicznokulturowej, Warszawa 2013.

Kręcidło J., Świadectwo Boga Ojca o Jezusie w Ewangelii wg św. Jana, Verbum Vitae 27 (2015), s. 147-167.

Kręcidło J., The Spirit Paraclete and Jesus in the Gospel of John, Kraków 2007.

Ksenofont, Wychowanie Cyrusa (Cyropedia), tłum. K. Głombiowski, B. Burliga i in., Biblioteka Antyczna, Wrocław 2014.

Louw J.P., Nida E.A., Greek-English Lexicon of the New Testament Based on Semantic Domains, t. 1-2, New York 1988.

Malina B.J., Rohrbaugh R.L., Social-Science Commentary on the Gospel of John, Minneapolis 1998.

Manns F., L'Évangile de Jean à la lumière du Judaïsme, Jerusalem 1991.

Publiusz Wergiliusz Maron, Eneida, tłum. T. Karyłowski, 10.729-741: http://biblioteka. kijowski.pl/antyk\%20rzymski/publiusz\%20wergiliusz\%20maro_eneida.pdf

Mędala S., Ewangelia według świętego Jana (rozdziały 13-21), Nowy Komentarz Biblijny. Nowy Testament t. IV, cz. 2, Częstochowa 2009.

Moloney F.J., The Gospel of John, Sacra Pagina Series 4, Collegeville 1998.

Moxnes H., Patron-Client Relationship and the New Community in Luke-Acts, w: J.H. Neyrey (red.), The Social World of Luke-Acts: Models for Interpretation, Peabody 1991, s. 241-268.

Neyrey J.H., Worship in the Fourth Gospel. A Cultural Interpretation of John 14-17, Biblical Theology Bulletin 36 (2006), s. 107-117.

Piper R.A., Glory, Honor and Patronage in the Fourth Gospel: Understanding the Doxa Given to Disciples in John 17, w: Social Scientific Models for Interpreting the Bible: Essays by the Context Group in Honor of Bruce J. Malina, Leiden 2001, s. 283-285 .

Platon, Apologia, czyli Obrona Sokratesa, tłum. F.A. Kozłowski, Warszawa 1845.

Stachowiak L., Modlitwa arcykapłańska: J 17, Roczniki Teologiczno-Kanoniczne 21/1 (1974), s. 85-94.

Stewart E.C., Social Stratification and Patronage in Ancient Mediterranean Societies, w: D. Neufeld, R.E. DeMaris (red.), Understanding the Social World of the New Testament, London 2010, s. 156-166. 
Thüsing W., Aby wszyscy stanowili jedno (J 17). Modlitwa arcykapłańska Jezusa (J 17), tłum. K. Bukowski, Kraków 1996.

Westcott B., The Gospel according to St. John: The Greek Text with Introduction and Notes, t. 2, London 1908.

Wróbel M.S., Obraz Boga Ojca, w: M. Rosik (red.), Teologia Nowego Testamentu. Tom II. Dzieło Janowe, Wrocław 2008, s. 11-38. 